\title{
Correction to: Effect of wheat germ on metabolic markers: a systematic review and meta-analysis of randomized controlled trials
}

\author{
Humna Liaqat ${ }^{1} \cdot$ Eunseon Jeong $^{1} \cdot \mathrm{Kyeong}_{\mathrm{Jin}} \mathrm{Kim}^{2} \cdot \mathrm{Ji}^{\mathrm{Yeon}} \mathrm{Kim}^{1,2}{ }_{(\mathbb{D}}$
}

(C) The Author(s) 2020

\section{Correction to: \\ Food Sci Biotechnol (2020) 29(6):739-749 \\ https://doi.org/10.1007/s10068-020-00769-9}

The article "Effect of wheat germ on metabolic markers: a systematic review and meta-analysis of randomized controlled trials", written by Humna Liaqat, Eunseon Jeong, Kyeong Jin Kim and Ji Yeon Kim, was originally published Online First without Open Access. After publication in volume 29, issue 6, pages 739-749 the author decided to opt for Open Choice and to make the article an Open Access publication. Therefore, the copyright of the article has been changed to (C) The Author(s) 2020 and the article is forthwith distributed under the terms of the Creative Commons Attribution 4.0 International License (http:// creativecommons.org/licenses/by/4.0/), which permits use, duplication, adaptation, distribution and reproduction in

The original article can be found online at https:// doi.org/10.1007/s10068-020-00769-9.

Ji Yeon Kim

jiyeonk@seoultech.ac.kr

Humna Liaqat

humnaliaqat710@gmail.com

Eunseon Jeong

todayjung@hanmail.net

Kyeong Jin Kim

jinnykim@seoultech.ac.kr

1 Department of Food Science and Technology, Seoul National University of Science and Technology, 232, Gongneung-ro, Nowon-gu, Seoul 01811, Korea

2 Department of Nano Bio Engineering, Seoul National University of Science and Technology, 232, Gongneung-ro, Nowon-gu, Seoul 01811, Korea any medium or format, as long as you give appropriate credit to the original author(s) and the source, provide a link to the Creative Commons license, and indicate if changes were made.

The original article has been corrected.

Open Access This article is licensed under a Creative Commons Attribution 4.0 International License, which permits use, sharing, adaptation, distribution and reproduction in any medium or format, as long as you give appropriate credit to the original author(s) and the source, provide a link to the Creative Commons licence, and indicate if changes were made. The images or other third party material in this article are included in the article's Creative Commons licence, unless indicated otherwise in a credit line to the material. If material is not included in the article's Creative Commons licence and your intended use is not permitted by statutory regulation or exceeds the permitted use, you will need to obtain permission directly from the copyright holder. To view a copy of this licence, visit http://creativecommons. org/licenses/by/4.0/.

Publisher's Note Springer Nature remains neutral with regard to jurisdictional claims in published maps and institutional affiliations. 